\title{
Uncoupling of the endocannabinoid signalling complex in a mouse model of fragile $\mathrm{X}$ syndrome
}

\author{
Kwang-Mook Jung ${ }^{1, \star}$, Marja Sepers ${ }^{2,3, \star}$, Christopher M. Henstridge ${ }^{4, \star}$, Olivier Lassalle $5,6,7$, \\ Daniela Neuhofer 5,6,7, Henry Martinn,6,7, Melanie Ginger ${ }^{2,3}$, Andreas Frick ${ }^{2,3}$, Nicholas V. DiPatrizio1, \\ Ken Mackie ${ }^{8}$, Istvan Katona ${ }^{4}$, Daniele Piomelli, ${ }^{1,9,10}$ \& Olivier J. Manzoni²,3,5,6,7
}

Fragile $X$ syndrome, the most commonly known genetic cause of autism, is due to loss of the fragile $X$ mental retardation protein, which regulates signal transduction at metabotropic glutamate receptor- 5 in the brain. Fragile $X$ mental retardation protein deletion in mice enhances metabotropic glutamate receptor-5-dependent long-term depression in the hippocampus and cerebellum. Here we show that a distinct type of metabotropic glutamate receptor-5-dependent long-term depression at excitatory synapses of the ventral striatum and prefrontal cortex, which is mediated by the endocannabinoid 2-arachidonoyl-sn-glycerol, is absent in fragile $X$ mental retardation protein-null mice. In these mutants, the macromolecular complex that links metabotropic glutamate receptor-5 to the 2-arachidonoyl-sn-glycerolproducing enzyme, diacylglycerol lipase- $\alpha$ (endocannabinoid signalosome), is disrupted and metabotropic glutamate receptor-5-dependent 2-arachidonoyl-sn-glycerol formation is compromised. These changes are accompanied by impaired endocannabinoid-dependent long-term depression. Pharmacological enhancement of 2-arachidonoyl-sn-glycerol signalling normalizes this synaptic defect and corrects behavioural abnormalities in fragile $\mathrm{X}$ mental retardation protein-deficient mice. The results identify the endocannabinoid signalosome as a molecular substrate for fragile $\mathrm{X}$ syndrome, which might be targeted by therapy.

\footnotetext{
${ }^{1}$ Department of Anatomy and Neurobiology, University of California, Irvine, California 92697, USA. ${ }^{2}$ INSERM U862, Circuit and Dendritic Mechanisms Underlying Cortical Plasticity Group, Neurocentre Magendie, 146 Rue Léo-Saignat, F 33077 Bordeaux Cedex, France. ${ }^{3}$ University of Bordeaux, Bordeaux F 33077, France. ${ }^{4}$ Institute of Experimental Medicine, Hungarian Academy of Sciences, H-1083 Budapest, Hungary. ${ }^{5}$ INSERM U901, Marseille 13009, France. ${ }^{6}$ Université de la Méditerranée UMR S901, Aix-Marseille 2, France. ${ }^{7}$ INMED, Marseille 13009, France. ${ }^{8}$ Department of Psychological and Brain Sciences, Gill Center for Biomolecular Science, Indiana University, Bloomington, Indiana 47405, USA. ${ }^{9}$ Department of Biological Chemistry, University of California, Irvine, California 92697, USA. 10 Unit of Drug Discovery and Development, Italian Institute of Technology, Genova 16163, Italy. ${ }^{*}$ These authors contributed equally to this study. Correspondence and requests for materials should be addressed to I.K. (email: katona@koki.hu) or to D.P. (email: piomelli@uci.edu) or to O.J.M. (email: olivier.manzoni@inserm.fr).
} 
F ragile $\mathrm{X}$ syndrome (FRAX), the most frequently known genetic cause of autism, is characterized by a series of physical, cognitive and emotional symptoms that include social deficits and diminished ability to learn ${ }^{1}$. FRAX is due to the mutation of a single gene, called FMR1 (ref. 2), which encodes for the fragile X mental retardation protein (FMRP) ${ }^{3}$. FMRP regulates the translation and transport of messenger RNAs in dendritic spines of brain neurons, and is involved in modulating signal transduction through type-I metabotropic glutamate $\left(\mathrm{mGlu}_{1}\right.$ and $\mathrm{mGlu}_{5}$ ) receptors at glutamatergic synapses throughout the brain. Loss of FMRP causes profound changes in the structure of neuronal dendrites and enhances, in the hippocampus and cerebellum of FMRP-deficient $\left(f \mathrm{mr}^{-/-}\right)$ mice, a form of long-term depression (LTD) that requires $\mathrm{mGlu}_{5}$ receptor-mediated protein synthesis ${ }^{3-7}$.

In medium spiny neurons of the ventral striatum and pyramidal neurons of the prefrontal cortex (PFC), activation of $\mathrm{mGlu}_{5}$ receptors initiates a distinct form of LTD, which does not depend on protein synthesis and is affected by the retrograde endocannabinoid (eCB) transmitter, 2-arachidonoyl-sn-glycerol (2-AG) ${ }^{8,9}$. Stimulation of $\mathrm{mGlu}_{5}$ receptors releases $2-\mathrm{AG}$ through the sequential recruitment of two enzymes: phospholipase C- $\beta$, which produces 1,2 -diacyl-snglycerol, and diacylglycerol lipase- $\alpha$ (DGL- $\alpha$ ), which converts 1,2-diacyl-sn-glycerol into 2-AG ${ }^{10-12}$. Morphological studies have shown that both phospholipase C- $\beta$ and DGL- $\alpha$ are localized to the perisynapse, a subdivision of the dendritic spine that forms a 100200-nm-thick border around the postsynaptic density ${ }^{13} \cdot \mathrm{mGlu}_{5}$ receptors are concentrated in this region ${ }^{14}$ where they may be physically linked to DGL- $\alpha$ through the adaptor protein Homer ${ }^{10,15}$. This supramolecular complex is likely to have an important role in eCBmediated transmission at excitatory synapses, by providing a focal point for the generation of a $2-\mathrm{AG}$ pool that is specifically committed to retrograde transmission. The $2-\mathrm{AG}$ produced by this complex can readily cross the synaptic cleft to access $\mathrm{CB}_{1}$ cannabinoid receptors on presynaptic terminals, where the 2-AG-deactivating enzyme monoacylglycerol lipase (MGL) is also found ${ }^{16,17}$. We propose that this complex, which we refer to as 'eCB signalosome', allows for the separation of the 2-AG pool responsible for eCB signalling from other cellular pools of 2-AG, such as those involved in eicosanoid production and phospholipid remodelling.

FMRP deletion is known to be associated with greater eCBmediated responses at GABAergic synapses of the dorsal striatum and CA1 region of the hippocampus ${ }^{18,19}$. Here, we show that loss of FMRP is accompanied by marked deficits in $\mathrm{mGlu}_{5}$-dependent 2-AG release and eCB-mediated LTD at excitatory synapses of the forebrain, as well as by a structural disorganization in the eCB signalosome. We further show that inhibition of presynaptic MGL activity normalizes eCB-mediated LTD and corrects key behavioural abnormalities in $f \mathrm{mrl}^{-/-}$mice, suggesting that pharmacological enhancement of 2-AG signalling might offer a new therapeutic strategy for FRAX.

\section{Results}

FMRP binds DGL- $\alpha$ mRNA and controls $2-A G$ signalling. FMRP regulates protein translation in postsynaptic spines by interacting with mRNAs that often, albeit not always, contain a G-quartet FMRP-binding motif ${ }^{20}$. A bioinformatics search showed that an FMRP-binding sequence is present in DGL- $\alpha$ mRNA (Fig. 1a), but not in mRNAs encoding for structurally or functionally related enzymes such as DGL- $\beta$, MGL, $N$-acylphosphatidylethanolamineselective phospholipase D (NAPE-PLD) and $\alpha / \beta$ hydrolase domain-6 (ABHD6) (data not shown). To test whether FMRP binds the DGL- $\alpha$ message, we immunoprecipitated FMRP from mouse forebrain homogenates and used quantitative PCR to measure DGL- $\alpha$ mRNA in the pellets. The pellets contained DGL- $\alpha$ mRNA (Fig. 1b), but no detectable levels of mRNAs encoding for DGL- $\beta$ or NAPE-PLD (Fig. 1c). As expected, the precipitates also contained mRNAs encoding for PSD-95 and amyloid precursor protein, which are known to bind FMRP 21,22 (Fig. 1d). Moreover, experiments with rat cortical neurons in primary cultures showed that exposure to the mixed $\mathrm{mGlu} / \mathrm{mGlu}_{5}$ receptor agonist (S)-3,5-dihydroxyphenylglycine (DHPG) $(100 \mu \mathrm{M})$ caused the dissociation between FMRP and DGL- $\alpha$ mRNA (Fig. 1e), as previously shown for other FMRP-regulated messages ${ }^{22}$.

To examine whether FMRP deletion influences $\mathrm{mGlu}_{5}$-dependent 2-AG signalling, we used mouse brain synaptoneurosomes, a subcellular preparation enriched in resealed postsynaptic spines attached to their corresponding axon terminals ${ }^{23}$. As expected for previous results ${ }^{10,11}$, incubation of wild-type synaptoneurosomes with DHPG resulted in a rapid increase in DGL activity, which was dependent on both incubation time and DHPG concentration (Fig. 2a,b), and was accompanied by an elevation in 2-AG levels (Fig. 2c). These effects were not associated with changes in DGL- $\alpha$ content (Fig. $2 \mathrm{~d}$ ) and were not prevented by the translation inhibitor cycloheximide (Supplementary Fig. S1A), indicating that they did not require the synthesis of new DGL- $\alpha$ protein. In synaptoneurosomes prepared from $f \mathrm{mrl}^{-/-}$mice, DHPG failed to stimulate DGL activity and 2-AG production (Fig. 2a-c), even though baseline levels of 2-AG were similar to those measured in wild-type controls (Supplementary Fig. S1B). The results suggest that genetic loss of FMRP disrupts $\mathrm{mGlu}_{5}$-dependent 2-AG signalling at excitatory synapses.

FMRP targets DGL- $\alpha$ to the perisynapse. One mechanism through which FMRP deletion might affect receptor-operated 2-AG production is by altering the structure of the supramolecular complex that couples $\mathrm{mGlu}_{5}$ receptors to DGL- $\alpha$ (which we refer to here as 'eCB signalosome'). To test this possibility, we immunostained for $\mathrm{mGlu}_{5}$ or DGL- $\alpha$ brain sections from wild-type and $f \mathrm{mrl}^{-/-}$ mice. We first focused on the core of the ventral striatum, a brain region in which the eCB system mediates excitatory $\mathrm{LTD}^{8}$. Immunoperoxidase labelling for $\mathrm{mGlu}_{5}$ or DGL- $\alpha$ revealed a dense punctuate distribution throughout the neuropil, which appeared to be similar between wild-type and $f m r 1^{-/-}$mice (Fig. 3a,b,g,h). Further analyses by immunogold electron microscopy revealed a widespread presence of $\mathrm{mGlu}_{5}$ and DGL- $\alpha$ in postsynaptic profiles-predominantly in dendritic spine heads that received asymmetric, putatively glutamatergic inputs from DGL- $\alpha$ or $\mathrm{mGlu}_{5^{-}}$ immunonegative axon terminals (Fig. $3 c, d, i, j)$. To assess whether FMRP deletion alters the subcellular distribution of $\mathrm{mGlu}_{5}$ and DGL- $\alpha$, in three separate experiments we measured the distance along the plasma membrane between the gold particles attached to DGL- $\alpha$ or $\mathrm{mGlu}_{5}$ and the closest edge of the postsynaptic density. There was no statistically detectable difference in the subcellular distribution of $\mathrm{mGlu}_{5}$ between wild-type and $\mathrm{fmr} \mathrm{I}^{-/-}$ mice ( $n=294$ and 285 synapses for wild-type and $f m r 1^{-1-}$ mice, respectively; Kolmogorov-Smirnov test, $P=0.917$ ) (Fig. 3k). By contrast, the cumulative distribution functions of the subcellular localization of DGL- $\alpha$ were significantly different between the two genotypes ( $n=259$ and 185 synapses for wild-type and $f m r 1^{-/-}$ mice, respectively; $P=0.001$ ) (Fig. $3 \mathrm{e}$ ). This suggests that FMRP deletion selectively impairs the subcellular targeting of DGL- $\alpha$ in postsynaptic spine heads, without affecting the targeting of $\mathrm{mGlu}_{5}$.

To investigate this phenomenon further, we divided the spinehead plasma membrane into $60-\mathrm{nm}$ bins and calculated the frequency of gold particles within each bin. As previously shown for the hippocampus ${ }^{13}$, particles associated with DGL- $\alpha$ were concentrated in the perisynaptic zone, with a gradient that decreased towards the spine neck, and were nearly absent from the intrasynaptic domain (Fig. 3f). This skewed distribution was clearly detectable in the ventral striatum core of wild-type mice, but was totally absent in $f \mathrm{mr}^{-/-}$mutants (Fig. 3f). Swapping all data points in the first 
a

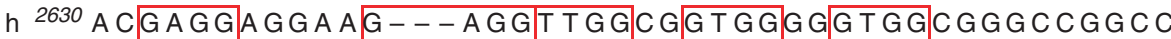

$\mathrm{m}^{2633}$ A A G A G A G G A G C C G C A GG T GG C A T T A G GG T GG T GGGG T G G C C

$r 2633$ A C G A G G A GG A G G C A G C C GG T G G C A G T G A G G T GG T G G G T T G G C C

b

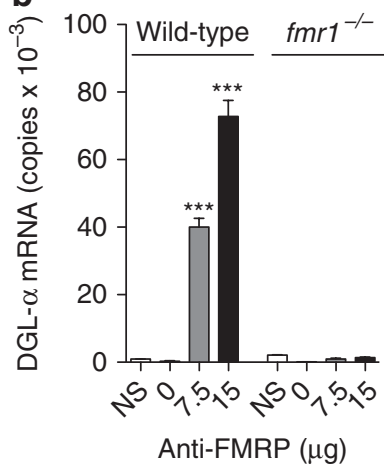

C

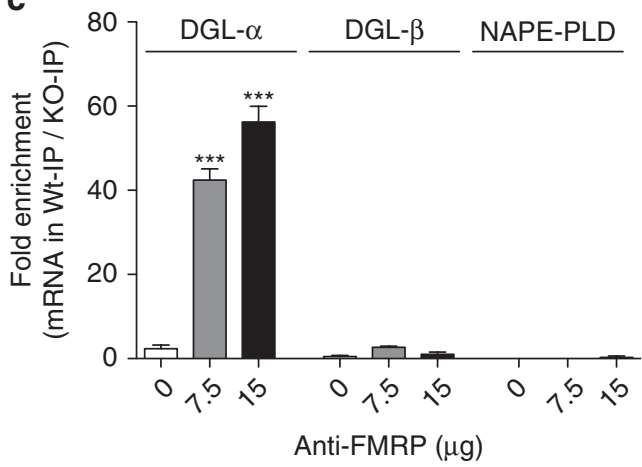

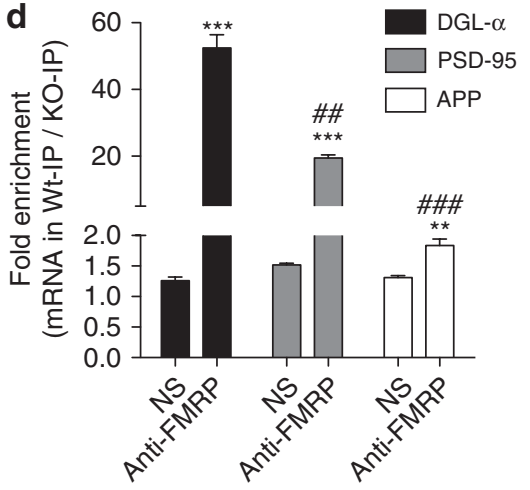

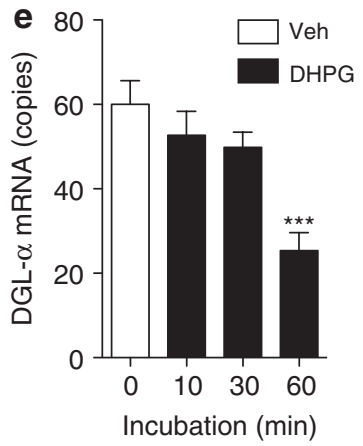

Figure 1 | DGL- $\alpha$ mRNA binds to FMRP. (a) Alignment of the coding region in human $(h)$, mouse $(m)$ and rat $(r)$. DGL- $\alpha$ mRNAs reveal a putative G-quartet sequence within a G-rich region containing several DWGG repeats. The canonical G-quartet motif is DWGG-N $(0-5)$-DWGG-N $(0-3)$-DWGG$\mathrm{N}_{(0-2)}$-DWGG, where $\mathrm{D}$ is any nucleotide except $\mathrm{C}$, and $\mathrm{W}$ is $\mathrm{A}$ or $\mathrm{U}$. The DWGG repeats are boxed in red. (b) Co-immunoprecipitation of FMRP with DGL- $\alpha$ mRNA. Brains from wild-type or $\mathrm{mmr}^{-/-}$mice were homogenized and centrifuged at $70,000 \mathrm{~g}$ for $30 \mathrm{~min}$. The supernatant (1 mg protein) was incubated with the indicated amounts of anti-FMRP antibody or normal serum (NS), and the immunocomplex was precipitated using protein G-sepharose beads. Top, levels of DGL- $\alpha$ mRNA in the immunoprecipitates were quantified by real-time quantitative PCR $\left(n=3,{ }^{\star \star \star} P<0.001\right)$. Bottom, a portion of the immunoprecipitate was subjected to SDS-PAGE and western blot analyses to confirm the presence of FMRP. (c,d) Analyses of mRNAs encoding for DGL- $\alpha$, DGL- $\beta$ and NAPE-PLD (c) or positive control PSD-95 and amyloid precursor protein (d) in anti-FMRP-immunoprecipitates $(n=3, * * P<0.01$ and

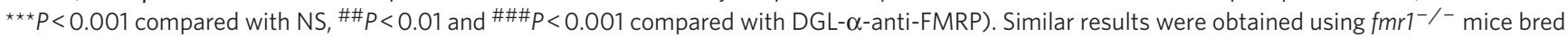
on either a FVB.129 background (b,c) or a C57BL/6J background (d). (e) DHPG-induced dissociation of DGL- $\alpha$ mRNA from FMRP in cultured cortical neurons. Rat primary neurons were prepared from embryonic day 18 cortex, as described ${ }^{55}$. Cells were treated with DHPG (100 $\mu M$ ) in culture medium and harvested at the indicated time. Levels of FMRP-bound DGL- $\alpha$ mRNA were determined by anti-FMRP immunoprecipitation and quantitative PCR, as described in Methods $\left(n=5,{ }^{* \star} P<0.001\right)$. Results are representative of at least two independent experiments. Significance was determined using two-tailed Student's t-test. Error bars represent s.e.m.

60 -nm bin of wild-type mice to the same data set of $f m r 1^{-/-}$animals and vice versa eliminated statistical significance (KolmogorovSmirnov test, $P=0.187$ and $P=0.332$ for wild-type to $f m r 1^{-/-}$swap and $f \mathrm{mr}^{-/-}$to wild-type swap, respectively). As swapping data sets in other bins did not reveal differences, the disappearance of DGL- $\alpha$ labelling from the perisynaptic domain may underlie the difference in the cumulative distribution functions. Furthermore, the same analytical approach revealed a biased perisynaptic localization of $\mathrm{mGlu}_{5}$ in both wild-type and $\mathrm{mrl}^{-1-}$ mice (Fig. 31 ).

To determine whether FMRP deletion influences the subcellular targeting of DGL- $\alpha$ in other forebrain structures, we examined the localization of $\mathrm{mGlu}_{5}$ and DGL- $\alpha$ in the CA1 subfield of the hippocampal formation, ${ }^{9,13,24,25}$. The perisynaptic localization of $\mathrm{mGlu}_{5}$ at hippocampal excitatory synapses was identical between 
$f m r 1^{-/-}$and wild-type mice, whereas the localization of DGL- $\alpha$ was markedly impaired in $f m r 1^{-/-}$mutants (Supplementary Fig. S2). An economical interpretation of these findings, which is consistent with our biochemical data, is that FMRP enables the correct targeting of DGL- $\alpha$ and its assembly with mGlu $_{5}$ into a functional eCB signalosome at excitatory synapses throughout the forebrain.

FMRP is a core component of the translational machinery in dendritic polyribosomes and has been implicated in the transport and localization of mRNAs to dendrites and synapses ${ }^{3}$.
We reasoned therefore that, in the absence of FMRP, DGL- $\alpha$ mRNA might be translated ectopically. Consistent with this prediction, an analysis of 300 synapses per genotype revealed an increased average density of intracellular DGL- $\alpha$ labelling in the ventral striatum of $f \mathrm{mr}^{-/}$- mice, compared with wild-type animals (0.91 (range: $0.6-1.43$ ) gold particles per $\mu \mathrm{m}^{2}$ and 3.02 (range: $2.19-3.63$ ) gold particles per $\mu \mathrm{m}^{2}$ in wild-type and $f \mathrm{mr}^{-/-}$animals, respectively, normalized to background levels) (Fig. $3 \mathrm{~m}$ ). This increase in normalized average density was also reflected in the ratio of intracellularly localized DGL- $\alpha$ (14\% (range: 10-17\%) and 36\% (range:
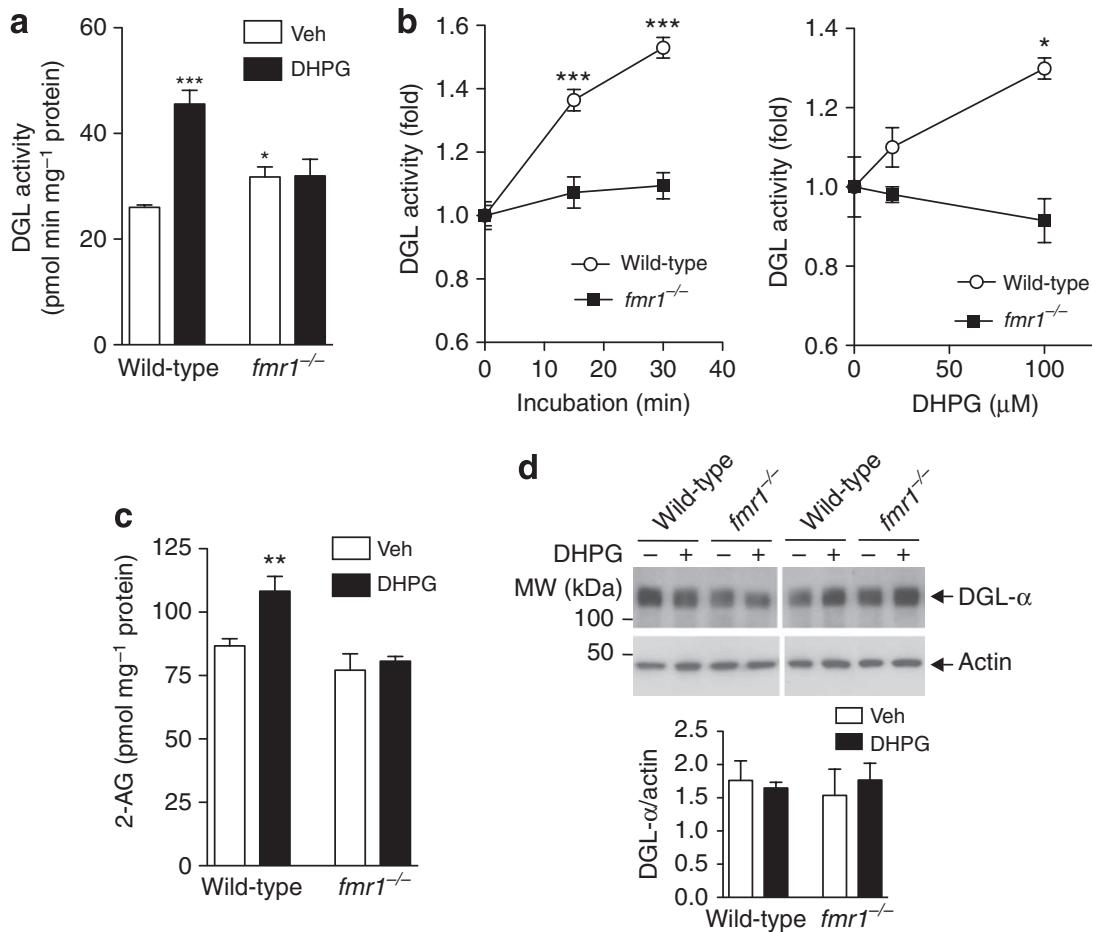

Figure $\mathbf{2}$ | $\mathbf{~ m G l u}_{\mathbf{5}}$ receptor-stimulated DGL activity and 2-AG release is disrupted in fmr1-/- mice. (a) Synaptoneurosome (SN) fractions prepared from wild-type or $\mathrm{fmr} 1^{-/-}$mice $\left(1 \mathrm{mg} \mathrm{ml}^{-1}\right)$ were incubated at $37^{\circ} \mathrm{C}$ for $30 \mathrm{~min}$ in the presence of $100 \mu \mathrm{M} \mathrm{DHPG}$, and DGL activity was measured in vitro using $10 \mu \mathrm{M}$ diheptadecanoylglycerol as a substrate $(n=4)$. (b) DGL activity was measured in SN fractions after incubation with various concentrations of DHPG $(n=3)$. (c) 2-AG levels in SN fractions were measured after 45-min incubation with DHPG (100 $\mu M)$ or vehicle $($ Veh, PBS) ( $n=5-9)$. (d). After treatment of synaptoneurosomes with DHPG, as described above, levels of DGL- $\alpha$ protein were measured by western blot. Representative images for DGL- $\alpha$ and loading control actin are shown ( $n=6$ each). Experiments were conducted on $f m r 1^{-/-}$mice on C57BL/6J (a,d) or FVB.129 background (b,c). Results are representative of at least two independent experiments. Significance was determined using two-tailed Student's $t$-test. ${ }^{\star} P<0.05,{ }^{\star \star} P<0.01$ and ${ }^{\star \star *} P<0.001$. Error bars represent s.e.m.

Figure 3 | Impaired targeting of DGL- $\alpha$ to the perisynaptic domain of excitatory synapses in $\mathbf{f m r 1 / -}$ mice. DGL- $\alpha$ immunoperoxidase labelling in wildtype (a) and $\mathrm{fmr}^{-/-}$mice (b) reveals a similar granular staining pattern in the neuropil of the accumbens/ventral striatum (arrowheads). Medium spiny neuron somata are devoid of labelling (asterisks). aco, anterior commissure. Electron micrographs of asymmetric synapses reveal that DGL- $\alpha$-positive gold particles (arrowheads) are predominantly found perisynaptically, close to the PSD (red arrows) in wild-type animals (c), but not in fmr $1^{-/-}$synapses (d) S, spine head; b, bouton. (e) Cumulative distribution plot of DGL- $\alpha$ localization in wild-type (solid line, $n=259$ ) and fmr1 ${ }^{-/-}$spines (dashed line, $n=185$ ). (f) Histogram summarizing the normalized distribution of DGL- $\alpha$-immunogold on the spine head membrane of wild-type mice (black arrow and black bars, $n=259$ ) and $\mathrm{fmr}^{-{ }^{--}}$mice (grey arrow and grey bars, $n=185$ ). Large arrow = edge of PSD. mGlu immunoperoxidase labelling in wild-type (g) and $\mathrm{fmr}^{-1^{-}}$animals (h) depicts a similar granular labelling pattern (arrowheads) as DGL- $\alpha$. Electron micrographs of asymmetric synapses containing mGlu ${ }^{-i m m u n o g o l d ~ l a b e l l i n g ~(a r r o w h e a d) ~ r e v e a l e d ~ t h a t ~} \mathrm{mGlu}_{5}$ was predominantly found perisynaptically (red arrows) in both wild-type (i) and fmr ${ }^{-/-}$ spines (j). (k) Cumulative distribution plot of mGlu $5^{-i m m u n o g o l d ~ l o c a l i z a t i o n ~ i n ~ w i l d-t y p e ~(s o l i d ~ l i n e, ~} n=294$ ) and fmr1 ${ }^{-/-}$mice (dashed line, $n=285$ ). (I) Histogram representing the normalized distribution of $\mathrm{mGlu}_{5}$-immunogold on spine heads of wild-type (black arrow and black bars, $n=294$ ) and $\mathrm{fmr}^{-{ }^{-}-}$spines (grey arrow and grey bars, $n=285$ ). The number of DGL- $\alpha$-positive spines was higher in $\mathrm{fmr} 1^{-/-}$mice; however, the density of spine head membrane labelling was the same in both strains. Instead, a significantly higher density of DGL- $\alpha$ labelling was found within the spine head and neck cytoplasm (arrowheads; $\mathbf{m 1} \mathbf{1} \mathbf{m} \mathbf{2}$ ) and along the spine neck membrane (black arrowheads; $\mathbf{n}$ ). Symmetrical synapses are considered inhibitory GABAergic inputs and frequently synapse onto spine necks (red arrowhead; $\mathbf{n}$ ) and dendritic shafts Importantly, the number of DGL- $\alpha$ positive symmetrical synapses were similar in wild-type (o) and $f m r 1^{-/-}$mice (p). Scale bars: $15 \mu \mathrm{m}$ in $\mathbf{a}, \mathbf{b}, \mathbf{g}$ and $\mathbf{h}$ and $100 \mathrm{~nm}$ in $\mathbf{c}, \mathbf{d}, \mathbf{i}, \mathbf{j}, \mathbf{m}-\mathbf{p}$. 
$33-46 \%)$ of all gold particles found in dendritic spine heads in wildtype and $\mathrm{fmrl}^{-/-}$animals, respectively). In another experiment, we assessed the presence of DGL- $\alpha$ labelling in a second data set of 75 random intact spines per animal. We found that $f m r 1^{-/-}$spines had a higher probability of DGL- $\alpha$ labelling than did wild-type spines $\left(\chi^{2}\right.$ test, $\left.P<0.001\right)$.

In which subcellular structure was DGL- $\alpha$ labelling concentrated? To address this question, we divided each spine into three distinct
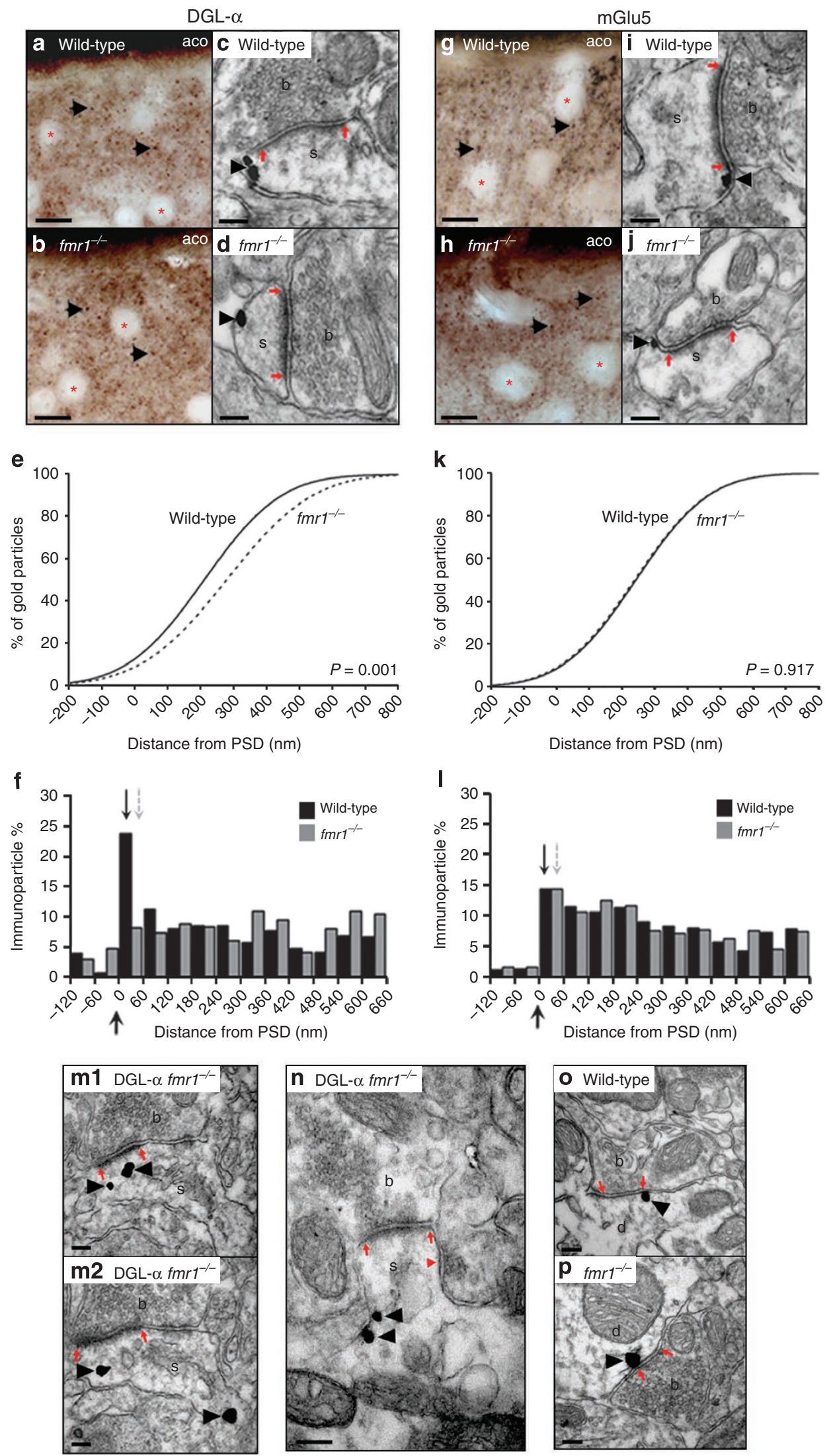
compartments: spine-head membrane, spine-neck membrane, and head and neck cytoplasm. The number of DGL- $\alpha$ gold particles on the spine head membrane was very similar between wild-type and $f m r 1^{-/-}$mice $\left(\chi^{2}\right.$ test, $\left.P=0.696\right)$. By contrast, we found a significantly higher number of DGL- $\alpha$ gold particles in spine neck membrane ( $\chi^{2}$ test, $\left.P<0.001\right)$ (Fig. $\left.3 \mathrm{n}\right)$ and cytoplasm $\left(\chi^{2}\right.$ test, $P=0.003$ ) of $f m r 1^{-/-}$mice. In agreement with previous studies ${ }^{26,27}$, we found that dendrites in $f \mathrm{mr}^{-/-}$mice exhibited longer spine necks than wild-type $\left(852 \pm 19\right.$ and $1030 \pm 24 \mathrm{~nm}$ in wild-type and $f \mathrm{mrl}^{-/-}$ respectively; Kolmogrov-Smirnov test, $P<0.001$ ), which might account for the higher number of DGL- $\alpha$ gold particles observed in these animals. However, when we calculated the density of DGL- $\alpha$ labelling for each spine compartment, this was also significantly higher in the $f m r 1^{-/}$necks than wild-type mice (2.29 (range: 1.63-3.01) gold particles per $\mu \mathrm{m}^{2}$ and 4.67 (range: $3.63-5.85$ ) gold particles per $\mu \mathrm{m}^{2}$ in wild-type and $f \mathrm{mrl}^{-/-}$animals, respectively). By contrast, the density of DGL- $\alpha$ labelling in the spine-head membrane was similar between the two strains (1.26 (range: $0.43-1.89$ ) gold particles per $\mu \mathrm{m}^{2}$ and 1.42 (range: $1.06-1.86$ ) gold particles per $\mu \mathrm{m}^{2}$ in wild-type and $f \mathrm{mr}^{-/-}$animals, respectively), but higher intracellular labelling was observed in $f \mathrm{mr}^{-/-}$mice (0.4 (range: $0.2-0.8$ ) gold particles per $\mu \mathrm{m}^{2}$ and 0.91 (range: $0.78-$ 0.92 ) gold particles per $\mu \mathrm{m}^{2}$ in wild-type and $f \mathrm{mr}^{-/-}$animals, respectively).

Finally, we examined whether FMRP deletion might affect DGL- $\alpha$ localization at GABAergic synapses, which are also dysfunctional in $f \mathrm{mrl}^{-/-}$mice ${ }^{18,19}$. DGL- $\alpha$ gold particles were found at the postsynaptic plasma membrane of both wild-type (Fig. 3o) and $f \mathrm{mr}^{-/-}$mice (Fig. 3p), but no statistically detectable difference was noted in their distribution ( $\chi^{2}$ test, $\left.P=0.6, n=150\right)$. The results suggest that genetic FMRP deletion alters the normal localization of DGL- $\alpha$ at excitatory, but not inhibitory, synapses of the forebrain, causing this enzyme to accumulate ectopically in the neck and cytoplasm of dendritic spines.

FMRP enables eCB-LTD in ventral striatum and PFC. The biochemical and ultrastructural results reported above suggest that FMRP deletion reduces 2-AG-dependent LTD at excitatory synapses of the forebrain. In acutely dissected brain slices from wild-type mice, low-frequency electrical stimulations $(10 \mathrm{~min}, 10 \mathrm{~Hz})$ elicited robust LTD of excitatory postsynaptic currents (EPSCs, Fig. 4a, white symbols) or extracellular field potentials (fEPSP, see Fig. 5a) in medium spiny neurons of the ventral striatum ${ }^{8}$. The induction of LTD was prevented by the DGL- $\alpha$ inhibitor tetrahydrolipstatin $(10 \mu \mathrm{M})$ (Fig. 4b), as expected from previous work ${ }^{9,28}$, and was not affected by pharmacological blockade of protein synthesis (Supplementary Fig. S3). Importantly, the samelow-frequency stimulations that caused LTD in wild-type mice failed to do so in $f \mathrm{mr}^{-/-}$mutants (Figs $4 \mathrm{a}$ and $5 \mathrm{a}$, black symbols). Moreover, bath applications of the mixed $\mathrm{mGlu}_{1} / \mathrm{mGlu}_{5}$ agonist, DHPG, which consistently elicited LTD in brain slices prepared from wild-type mice, were ineffective in slices obtained from $\mathrm{fmrl}^{-/-}$mutants (Fig. 4c). To evaluate whether the deficits in eCB-LTD observed in $f m r 1^{-/-}$mutants extended beyond the ventral striatum, we took advantage of the fact that this brain region receives major excitatory projections from the medial PFC, a structure where $\mathrm{mGlu}_{5}$ activation also underlies 2-AG-dependent eCB-LTD at synapses of pyramidal neuron layers $2 / 3$ and $5 / 6$ (refs 9,29). Similar to the ventral striatum, eCB-LTD was absent in PFC slices obtained from $f m r 1^{-/-}$mutants (Fig. $4 \mathrm{~d}$ ). Together, these results support the idea that FMRP deletion causes a widespread impairment of $\mathrm{mGlu}_{5}$-dependent LTD at excitatory synapses.

To test the alternative possibility that the LTD deficit observed in fmr1 $1^{-/}$mice might result from impaired $\mathrm{CB}_{1}$ receptor function, we assessed the ability of the cannabinoid agonist CP55940 (0.01$10 \mu \mathrm{M})$ to inhibit synaptic transmission in slices of ventral striatum prepared from wild-type or $f m r 1^{-/-}$mice. The drug's potency and efficacy were identical in the two strains (Supplementary Fig. S4A), indicating that $\mathrm{CB}_{1}$ receptors function normally in $\mathrm{fmrl}^{-/-}$mice. Moreover, tonic eCB signalling did not appear to be affected by FMRP deletion, because the selective $\mathrm{CB}_{1}$ inverse agonist AM251 ( $4 \mu \mathrm{M}$, applied $30 \mathrm{~min}$ before testing) did not alter baseline excitatory transmission in the ventral striatum of wild-type or $f m r 1^{-/-}$ mice (Supplementary Fig. S4B). Thus, the lack of eCB-dependent plasticity observed in $\mathrm{fmr} \mathrm{I}^{-/-}$mice cannot be accounted for by alterations in $\mathrm{CB}_{1}$ function or tonic eCB activity. We also compared the intrinsic properties of ventral striatum medium spiny neurons in wild-type and $\mathrm{mrl}^{-/-}$mice, and found no difference in medium spiny neurons excitability (Supplementary Fig. S5). Deletion of FMRP may negatively impact the basic properties of ventral striatum excitatory synapses and, to test for this possibility, we recorded AMPA receptor-mediated spontaneous EPSCs (sEPSCs) in medium spiny neurons of both genotypes. The amplitude and frequency of AMPAR sEPSCs were similar in wild-type and $f \mathrm{mrl}^{-/-}$mice (Supplementary Fig. S6). The results rule out the possibility that modifications of excitability or basal synaptic properties of ventral striatum medium spiny neurons may be responsible for impaired eCB-LTD in $f m r 1^{-l-}$ mice.

To test whether FMRP might influence intracellular signal transduction pathways mediating other forms of LTD, we also analysed the LTD evoked by presynaptic $\mathrm{mGlu}_{2 / 3}$ receptors, which utilizes the same transduction mechanisms that are engaged by presynaptic $\mathrm{CB}_{1}$ receptors ${ }^{30,31}$. Bath application of the selective $\mathrm{mGlu}_{2 / 3}$ agonist LY379268 (100 nM) produced comparable levels of LTD in wild-type and $f \mathrm{mr}^{-/-}$mice (Supplementary Fig. S7). Together, our experiments support the conclusion that FMRP enables $\mathrm{mGlu}_{5}$ to initiate retrograde $2-\mathrm{AG}$ signalling and elicit LTD at excitatory synapses of the forebrain.

Enhancement of 2-AG signalling normalizes LTD in $\mathrm{fmrl}^{-/-}$ mice. The results reported above suggest that, in $\mathrm{fmrl}^{-/-}$mice, the failure of DGL- $\alpha$ to associate with $\mathrm{mGlu}_{5}$ into a functional eCB signalosome results in a loss of eCB-LTD. We have previously shown that pharmacological blockade of intracellular 2-AG hydrolysis, which is predominantly catalysed by presynaptic MGL ${ }^{16,32}$, lowers the threshold for LTD induction at excitatory synapses of the ventral striatum ${ }^{9,29}$. We hypothesized therefore that inhibitors of $2-A G$ degradation might normalize LTD in $f \mathrm{mrl}^{-/-}$mice by reinforcing 2-AG activity at residual intact synapses or, possibly, extending the reach of ectopically produced $2-A G$. To test this possibility, we blocked 2-AG hydrolysis in slices using the potent and irreversible MGL inhibitor, JZL184 ${ }^{33}$. Brain slices were incubated with JZL184 $(1 \mu \mathrm{M})$ for $45-90 \mathrm{~min}$ before LTD induction. This treatment was sufficient to restore both synaptic and pharmacologically induced LTD in slices prepared from $f m r 1^{-1-}$ mutants (Fig. 5a,b), but had no effect in slices from wild-type controls (Supplementary Fig. S8). In addition, inhibition of the postsynaptic 2-AG-hydrolysing enzyme ABHD6 $^{29}$ with WWL70 $(10 \mu \mathrm{M}, 45-90$-min incubation) also restored LTD in slices from ventral striatum of $f m r 1^{-/}$mice (Fig. 5a,b). The effects of JZL184 and WWL70 indicate that pharmacological blockade of either presynaptic or postsynaptic 2-AG degradation rescues eCB-dependent LTD in $f m r 1^{-/-}$mice.

Enhancing 2-AG corrects behavioural changes in $\mathrm{fmrl}^{-/-}$mice. When bred on a C57BL/6 background, $f m r 1^{-/-}$mice display a behavioural phenotype that is characterized by elevated motor activity in an open field (Fig. 6a,b) and decreased aversion to the open arms of an elevated plus maze ${ }^{34}$ (Fig. 6c,d). The MGL inhibitor JZL184 (16 mg kg-1, intraperitoneal) increased brain 2-AG levels (Supplementary Fig. S9A) and corrected these behavioural abnormalities within $6 \mathrm{~h}$ of administration (Fig. $6 \mathrm{a}-\mathrm{d}$ ). In $\mathrm{fmr1} \mathrm{m}^{-/-}$ mice, JZL184 reduced the number of squares crossed (Fig. 6a) and the total distance travelled (Fig. 6b) in the open field test. 


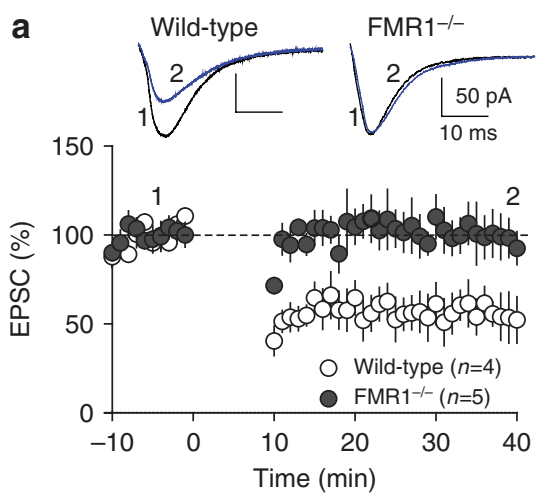

b
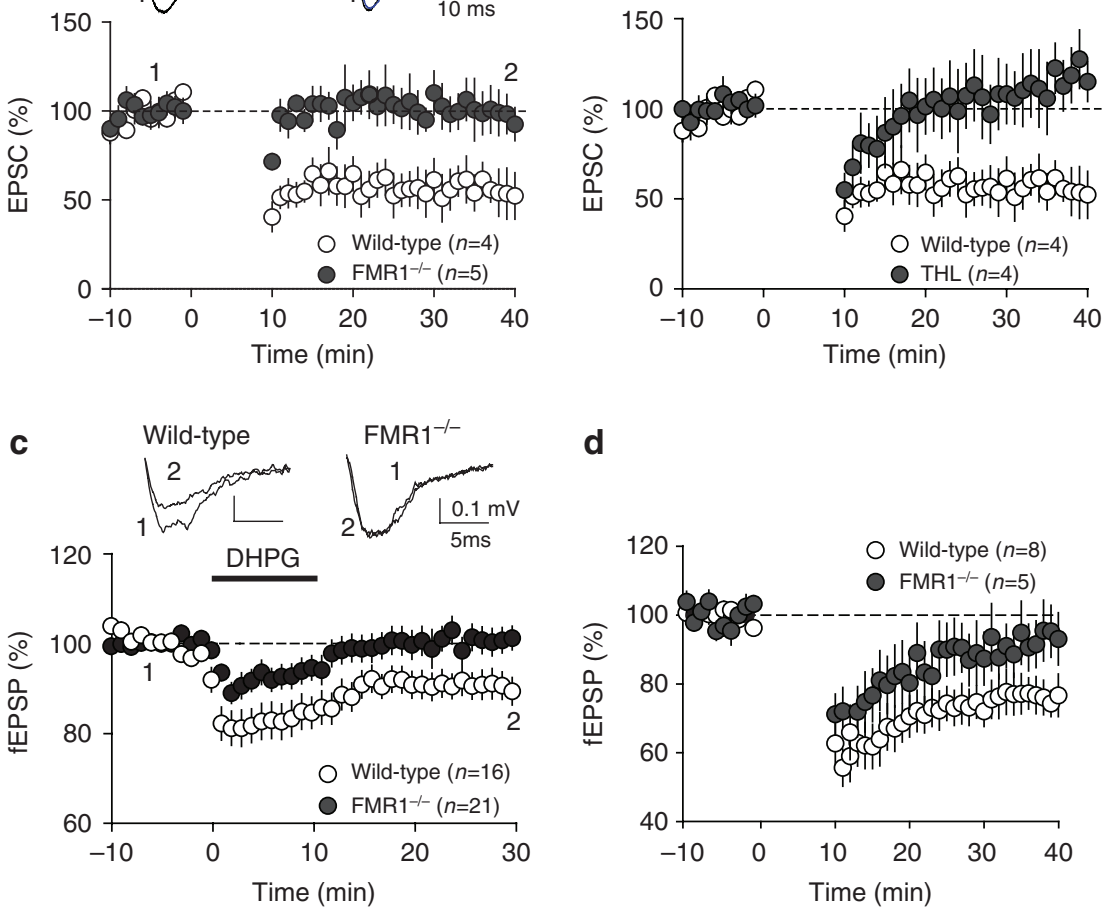

d

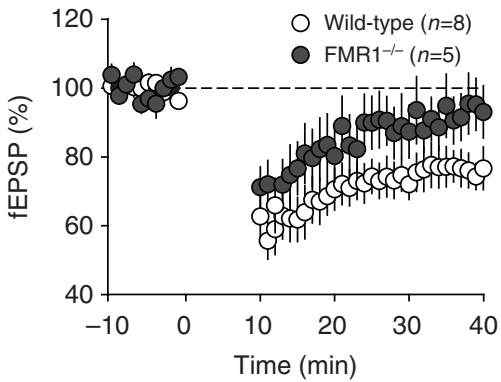

Figure 4 | LTD is abolished in ventral striatum and PFC of $\mathbf{f m r \mathbf { 1 } ^ { - / - }}$ mice. (a) Summary graph showing whole-cell evoked EPSC amplitudes. Values are normalized to baseline before the induction of LTD and averaged per minute. Tetanic stimulation ( $10 \mathrm{~min}$ at $10 \mathrm{~Hz}$ starting at time 0 ) of PFC afferent fibres to medium spiny neurons in the ventral striatum induces a robust LTD in wild-type littermates (open symbols, $n=4$ ) but not $f m r 1^{-/-}$mice (filled symbols, $n=5$ ). Here as in all physiology figures, $n$ equals the number of animals. (b) Summary graph showing averaged time courses of the experiments in which the $10 \mathrm{~min}$ at $10-\mathrm{Hz}$ protocol was given in control ACSF (open symbols, $n=4$ ) and after pre-treatment with tetrahydrolipstatin (THL, $10 \mu \mathrm{M}$, filled symbols, $n=4)$, an inhibitor of the DGL- $\alpha$. Graphs show EPSC amplitudes normalized to baseline before the induction of LTD and averaged per minute. (c) Direct pharmacological activation of $\mathrm{mGlu}_{1 / 5}$ with $50 \mu \mathrm{M}(\mathrm{S}$ )-DHPG induces LTD in the ventral striatum of wild-type littermates (open symbols, $n=16$ ) but not $\mathrm{fmr}^{-/-}$mice (filled symbols, $n=21$ ). Summary graphs show excitatory postsynaptic field potentials (fEPSP) amplitudes. (d) Summary graph showing fEPSP amplitudes recorded in pyramidal neurons of the PFC. Values are normalized to baseline before the induction of LTD and averaged per minute. Tetanic stimulation ( $10 \mathrm{~min}$ at $10 \mathrm{~Hz}$ starting at time 0 ) of layers $2 / 3$ to layers $5 / 6$ pyramidal synapses induces a robust LTD in wild-type littermates (open symbols, $n=8$ ) but not $\mathrm{fmr}^{-{ }^{-1}}$ mice (filled symbols, $n=5$ ). Statistical significance was determined using Mann-Whitney $U$-test. Error bars represent s.e.m.

The compound also reduced the number of entries and the time spent in the open arm in the elevated plus maze test (Fig. 6c,d and Supplementary Fig. S9C, D). By contrast, JZL184 did not significantly affect open field or elevated plus maze behaviours in wild-type mice (Fig. 6a-d and Supplementary Fig. S9B-D). These experiments suggest that pharmacological enhancement of 2-AG signalling normalizes two key behavioural changes observed in $f \mathrm{mrl}^{-}{ }^{-}$mice.

\section{Discussion}

In the present study, we provide three lines of evidence indicating that FMRP exerts a tight regulatory control over 2-AG-dependent retrograde signalling at excitatory synapses of the mouse forebrain. First, we show that an FMRP antibody selectively immunoprecipitates DGL- $\alpha$ mRNA in forebrain synaptoneurosome extracts. This is suggestive of a direct association between the two molecules, possibly through an interaction of FMRP with the G-quartet motif of DGL- $\alpha$ mRNA $^{35}$. Second, we report that the normal perisynaptic colocalization of DGL- $\alpha$ and $\mathrm{mGlu}_{5}$ is severely impaired in $f \mathrm{mr}^{-/-}$ mice, indicating that FMRP is necessary for the correct targeting of DGL- $\alpha$ to dendritic spines. Finally, we find that FMRP deletion disrupts both $\mathrm{mGlu}_{5}$-stimulated $2-\mathrm{AG}$ production in synaptoneurosomes and LTD at excitatory synapses of the ventral striatum and PFC. These findings suggest that FMRP may direct the assembling of DGL- $\alpha$ and $\mathrm{mGlu}_{5}$ into a functional signalosome, and is essential for retrograde 2-AG transmission at glutamatergic synapses (Fig. 7). Underscoring the functional significance of these results, we show that pharmacological blockade of 2-AG degradation reinstates eCB-dependent LTD and corrects key behavioural changes in $f m r 1^{-/-}$mice.

The eCB 2-AG is considered to be a primary effector of $\mathrm{mGlu}_{5^{-}}$ dependent plasticity in the brain ${ }^{9,12,28}$, but the dynamics of 2-AG signalling at central synapses are still unclear. One important question pertains to the mechanism through which mGlu $_{5}$ activation stimulates production of the 2-AG pool responsible for retrograde $\mathrm{eCB}$ transmission. Based on the present results, we hypothesize that the stable association of $\mathrm{mGlu}_{5}$ and DGL- $\alpha$ into a multiprotein complex at the perisynaptic annulus of the dendritic spine provides a structural scaffold that allows for the localized formation of a signalling-competent pool of 2-AG, which may be distinct from the intracellular 2-AG pools involved in phospholipid remodelling and eicosanoid biosynthesis ${ }^{36,37}$. We propose to call this complex 'eCB signalosome', to signify its pivotal role in eCB-mediated retrograde transmission (Fig. 7).

How does the lack of FMRP expression alter the structure of the eCB signalosome? The available data suggest two possibilities. The first is that, in the absence of FMRP, the DGL- $\alpha$ message may 

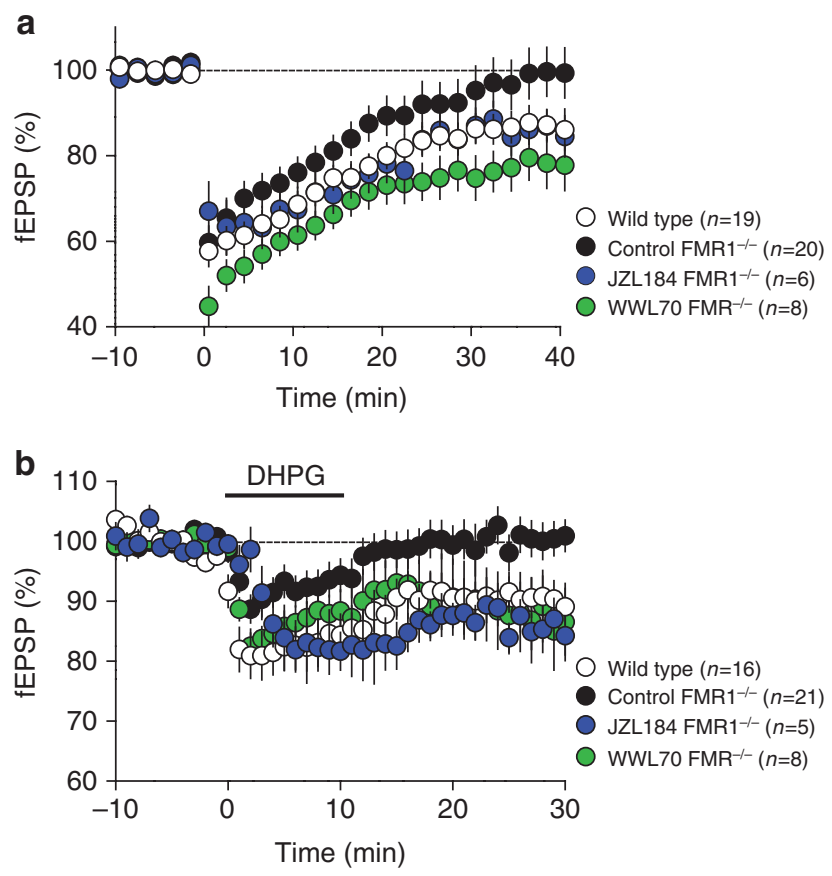

Figure 5 | Inhibitors of 2-AG degradation rescues eCB-dependent LTD in fmr1 $\mathbf{1}^{-/-}$mice. (a) Normalized fEPSP amplitude in $\mathrm{fmr1}^{-/-}$mice without ( $n=20$; black symbols) or with JZL184 $(1 \mu \mathrm{M}$; blue symbols, $n=6)$ or WWL70 $(10 \mu \mathrm{M}$; green symbols, $n=8)$ pretreatment (starting 45-90 min before LTD induction) followed by the LTD induction protocol at time zero. (b) Normalized fEPSP amplitude in $\mathrm{fmr}^{-/-}$mice without $(n=20$; black symbols) or with JZL184 ( $1 \mu \mathrm{M}$; blue symbols, $n=5)$ or WWL70 $(10 \mu \mathrm{M}$; green symbols, $n=8)$ pretreatment (starting 45-90 min before LTD induction) followed by 10 -min bath perfusion with $50 \mu \mathrm{M}(\mathrm{S})$-DHPG at time zero. Statistical significance was determined using Mann-Whitney $U$-test. Error bars represent s.e.m.

be incorrectly targeted within the dendritic spines, leading to errors in the timing of DGL- $\alpha$ translation or the localization of the translated protein. An error in spatial mRNA delivery caused by FMRP deletion was recently demonstrated for another key postsynaptic protein, calmodulin-activated protein kinase $\mathrm{II}^{38}$. A second possibility is that FMRP deletion may produce an alteration in the function of Homer proteins. These scaffolding proteins bind both $\mathrm{mGlu}_{5}$ and DGL- $\alpha^{10}$, and single-point mutations in the Homer-2-binding region of DGL- $\alpha$ result in an enzyme that retains functional activity, but is found in intracellular membrane compartments rather than the plasma membrane ${ }^{10}$. Notably, uncoupling of $\mathrm{mGlu}_{5}$ from the postsynaptic Homer scaffold results in the absence of mGluactivated retrograde 2 -AG signalling at excitatory synapses ${ }^{39}$. Previous studies suggest a similar functional uncoupling between $\mathrm{mGlu}_{5}$ and Homer-2 in $\mathrm{fmrl}^{-/-}$mice, despite comparable protein levels in synaptoneurosome preparations ${ }^{40}$. In support of this idea, an altered balance in $\mathrm{mGlu}_{5}$ scaffolding between short-form Homer 1a and long-form Homer proteins was found in $\mathrm{fmrl}^{-/-}$mice ${ }^{41}$. The hypotheses outlined above will be tested in future experiments.

The mGlu receptor theory of FRAX is based on the seminal observation that $f \mathrm{mr}^{-/-}$mice display a marked enhancement of a form of hippocampal LTD that depends on mGlu receptormediated protein synthesis ${ }^{3,5-7}$. Consistent with this theory, the eCB-mediated LTD induced at CA1 GABAergic synapses by pharmacological activation of $\mathrm{mGlu}_{5}$ is similarly enhanced in $f \mathrm{mr}^{-/-}$ mice ${ }^{18}$. Likewise, in the dorsal striatum of these mutants $\mathrm{mGlu}_{5^{-}}$ mediated eCB activity at GABAergic synapses is increased ${ }^{19}$. The present results, showing that eCB-LTD is abolished in the PFC and
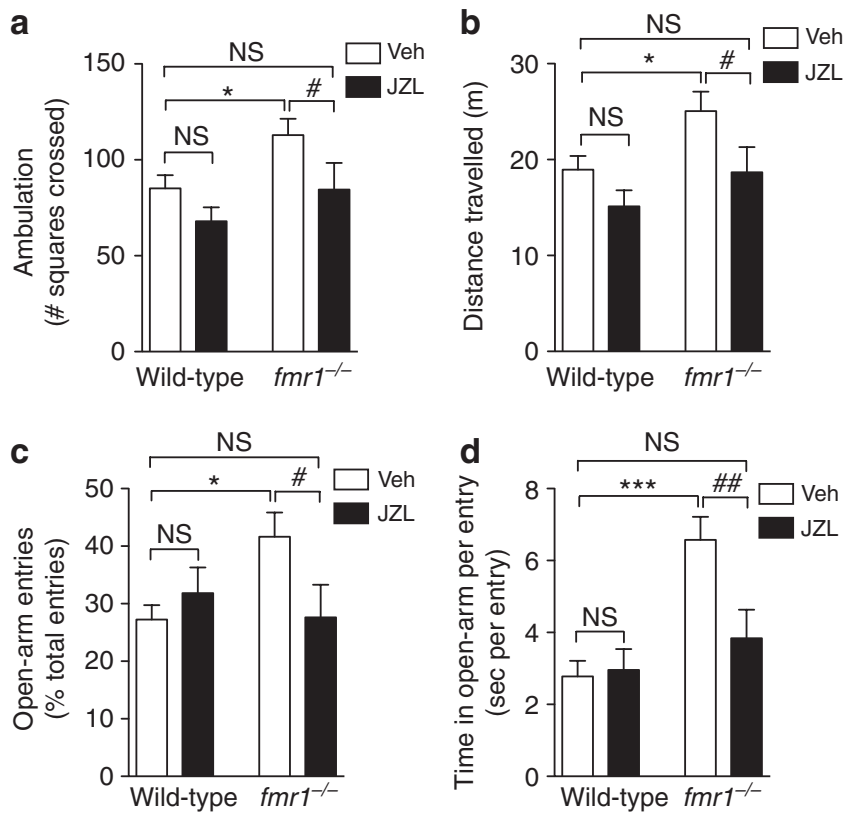

Figure 6 | MGL inhibition normalizes behavioural alterations in fmr1-/mice. Effects of the MGL inhibitor JZL184 on open field (a,b) and elevated plus maze (c,d) behaviours. Wild-type and $\mathrm{fmr}^{-/-}$mice received JZL184 (JZL, $16 \mathrm{mg} \mathrm{kg}^{-1}$, intraperitoneal) or vehicle (Veh), and were tested $6 \mathrm{~h}$ after injections. Activity in the open field was measured by counting the number of squares crossed (a) and total distance travelled (b). In the elevated plus maze test, we measured percentage of open arm entries (c) and average time in open per each entry (d). Significance was determined using two-way analysis of variance with post-hoc StudentNewman-Keuls test. NS, not significant; ${ }^{\star} P<0.05$, and ${ }^{\star \star \star} P<0.001$ compared with wild-type-Veh; ${ }^{\#} P<0.05$, and ${ }^{\# \#} P<0.01$ compared with $f m r 1^{-/-}-$Veh ( $n=11$ per each group). Error bars represent s.e.m.

ventral striatum of $f m r 1^{-/-}$mice, are only apparently in opposition with those data. Indeed, the notion that different neuron and synapse types adapt differently to the lack of FMRP is supported by a recent study showing that $m$ Glu receptor-dependent LTP is reduced in the lateral amygdala of $f m r 1^{-/-}$mice ${ }^{42}$. Although we found no changes in DGL- $\alpha$ density at GABAergic synapses, 2-AG signalling was suggested to be heterosynaptic between glutamatergic and GABAergic synapses ${ }^{43}$ (that is, $2-A G$ released from dendritic spines might activate $\mathrm{CB}_{1}$ receptors on more distant GABAergic terminals). Thus, it is possible that the shifted DGL- $\alpha$ localization gradient from the perisynaptic annulus to the spine neck compartment, where GABAergic synapses are often present (for example see red arrowhead in Fig. 3n), may underlie the opposite alterations in $\mathrm{CB}_{1}$-dependent regulation of synaptic plasticity between these synapses (refs 18,19 and present study). Our findings are in line, therefore, with the core prediction of the mGlu receptor theory-namely, the idea that loss of FMRP alters most consequences of $\mathrm{mGlu}_{5}$ activation $^{44}$. On the other hand, the present results reveal molecular disparities between excitatory and inhibitory synapses of the same brain region, and highlight that distinct forms of LTD may also behave differentially in FRAX. While protein synthesisdependent LTD is enhanced, presynaptic $\mathrm{mGlu}_{2 / 3}$-dependent LTD is unaffected, and finally the protein synthesis-independent, but eCB-mediated, LTD is absent. This palette of synaptic changes might underlie the complex neurobehavioural abnormalities observed in FRAX patients.

Pharmacological or genetic modulation of $\mathrm{mGlu}_{5}$ signalling normalizes various functional and structural aberrations occurring in 


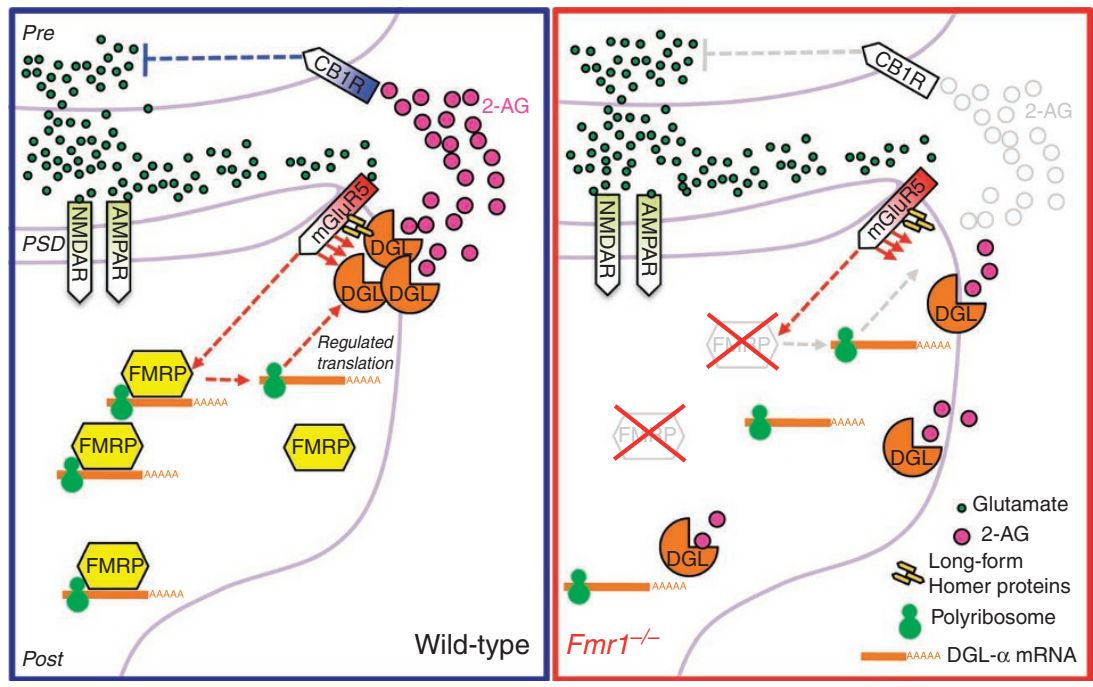

Figure 7 | Hypothetical role of FMRP in eCB-mediated retrograde transmission. At glutamatergic synapses of wild-type mice (left), mGlu 5 receptors and $\mathrm{DGL}-\alpha$ are linked together in a postsynaptic signalling complex (eCB signalosome), which includes the scaffolding protein Homer. Stimulation of mGlu 5 receptors (mGluR5) by glutamate (green circles) increases DGL- $\alpha$ activity (red arrows), causing a localized rise in 2-AG levels at the perisynapse. 2-AG (red circles) travels across the synaptic cleft and inhibits glutamate release by stimulating $\mathrm{CB}_{1}$ receptors (CB1R) on nerve endings. We hypothesize that FMRP helps target DGL- $\alpha$ to the eCB signalosome, possibly by positioning the DGL- $\alpha$ or Homer message(s) in specific subcellular nanodomain(s). In $\mathrm{fmr}^{1^{-/}}$mice (right), the lack of FMRP expression leads to disruption of this spatial organization, loss of localized 2-AG production and, consequently, impaired retrograde 2-AG-mediated signalling. AMPAR, AMPA receptors; NMDAR, NMDA receptors; PSD, postsynaptic density. Red arrows indicate intracellular signalling pathways triggered by the activation of mGlu${ }_{5}$ receptors. Molecular pathways that are impaired in $f \mathrm{mr}^{-/{ }^{-}}$mice are shown in grey.

fmr1 $1^{-/-}$mice-including hippocampal LTD, immature dendritic arbourization and behavioural deficits ${ }^{44}$. However, this approach is unlikely to restore LTD at synapses of the ventral striatum and the $\mathrm{PFC}$, where we find $\mathrm{mGlu}_{5}$-dependent eCB production to be downregulated. We reasoned therefore that one possible alternative could be to restore eCB-mediated plasticity by reducing the degradation of its main effector, 2-AG. We used JZL184, an irreversible inhibitor of the 2-AG-degrading enzyme $\mathrm{MGL}^{33,45,46}$. This compound proved to be effective at restoring eCB-LTD in ventral striatum slices as well as correcting two key behavioural changes observed in $f \mathrm{mr}^{-/-}$ mice-elevated motor activity in an open field and decreased aversion to the open arms of an elevated plus maze ${ }^{34}$. Despite these promising findings, the therapeutic potential of JZL184 might be limited by its ability to induce $\mathrm{CB}_{1}$ receptor desensitization ${ }^{46}$. Future experimentation will be required to assess whether other classes of MGL inhibitors (for example, reversible inhibitors) ${ }^{47}$ or agents that block additional 2-AG-hydrolysing enzymes, such as ABHD6 ${ }^{29}$, might normalize behaviour in $f \mathrm{mrl}^{-/-}$mice without inducing $\mathrm{CB}_{1}$ desensitization. Supporting the latter possibility, we observed here that acute blockade of ABHD6 re-establishes eCB-LTD in ventral striatum slices from $f m r 1^{-/-}$mice.

In conclusion, our results indicate that FMRP expression is necessary for the correct assembling of the eCB signalosome at glutamatergic synapses of the frontal cortex and ventral striatum core, and identify this macromolecular complex as a previously unknown substrate for FRAX, which might be targeted by therapy.

\section{Methods}

Physiology. Animals were treated in compliance with the European Communities Council Directive (86/609/EEC) and the United States National Institutes of Health Guide for the Care and Use of Laboratory Animals. All animals were housed, grouped and acclimated to laboratory conditions for 4 days before experiments with 12-h light/dark cycles, and access to food and water ad libitum.

Male $\mathrm{fmrl}^{-/-}$mice on a C57BL/6J genetic background ${ }^{48}$ aged 4 to 12 weeks $\left(f m r 1^{-1-}\right)$ were used, with wild-type littermates used as control group. They were anesthetized with isoflurane and decapitated according to institutional regulations.
The brain was sliced $(300 \mu \mathrm{m})$ in the coronal plane with a vibratome (Integraslice, Campden Instruments, Loughborough, UK) in a sucrose-based solution at $4{ }^{\circ} \mathrm{C}$ (in mM: $87 \mathrm{NaCl}$, 75 sucrose, 25 glucose, $5 \mathrm{KCl}, 21 \mathrm{MgCl}_{2}, 0.5 \mathrm{CaCl}_{2}$ and 1.25 $\mathrm{NaH}_{2} \mathrm{PO}_{4}$ ). Immediately after cutting, slices were stored at room temperature in a low-calcium artificial cerebrospinal fluid (low $\mathrm{Ca}$-ACSF) that contained (in $\mathrm{mM}$ ): $130 \mathrm{NaCl}, 11$ glucose, $2.5 \mathrm{KCl}, 2.4 \mathrm{MgCl}_{2}, 1.2 \mathrm{CaCl}_{2}, 23 \mathrm{NaHCO}_{3}$ and $1.2 \mathrm{NaH}_{2} \mathrm{PO}_{4}$, and was equilibrated with $95 \% \mathrm{O}_{2} / 5 \% \mathrm{CO}_{2}$ until the time of recording.

Whole-cell patch-clamp of visualized medium spiny neurons, PFC pyramidal neurons and field potential recordings were made in coronal slices containing the ventral striatum or the PFC as previously described ${ }^{8,9,49,50}$. For more details, see Supplementary Methods.

All values are given as mean \pm s.e.m. For all experiments, $n$ corresponds to the number of animals tested for each condition. Data were analysed using Clampfit 10 (Molecular Devices, Sunnyvale, USA). Unless otherwise stated, the statistical test used was a Mann-Whitney $U$-test performed with GraphPad Prism (GraphPad Software, La Jolla, CA) and significance determined by $P<0.05$. The magnitude of LTD was calculated by comparing average responses $(30-40 \mathrm{~min})$ after induction to baseline-averaged responses before induction protocol (increased stimulation for $10 \mathrm{~min}$ at $10 \mathrm{~Hz}$ ).

Picrotoxin, THL and anisomycin were from Sigma (St Quentin Fallavier, France). 6,7-dinitroquinoxaline-2,3-dione (DNQX), (1R,3R,4R)-3-[2-hydroxy4-(1,1-dimethylheptyl)-phenyl]-4-(3-hydroxypropyl)-cyclohexan-1-ol (CP55940), DHPG, AM251, WWL70 and JZL184 were from Tocris (Bristol, UK). Other chemicals were of the highest commercial grade available.

Biochemistry. Male $f m r 1^{-/-}$mice (FVB.129P2-Fmr $1^{\mathrm{tm} 1 \mathrm{Cgr} / J)}$ and wild-type control mice (FVB.129P2-Pde6b ${ }^{+} \mathrm{Tyr}^{\mathrm{c}-\mathrm{ch}}$ /AntJ) from Jackson Laboratories (Bar Harbor, ME), aged between 6 to 10 weeks, or adult male $\mathrm{fmrl}^{-1-}$ mice on C57BL/6J background (Fmr1 KO2) were used for the biochemical studies. All procedures met the National Institutes of Health guidelines for the care and use of laboratory animals and were approved by the University of California, Irvine, Institutional Animal Care and Use Committee.

All manipulations of brain homogenates were performed at $4^{\circ} \mathrm{C}^{51}$. Synaptoneurosomes were prepared from whole brains of wild-type or $\mathrm{fmrl}^{-/-}$mice. Briefly, mice were quickly decapitated, brains were removed and homogenized by 20 strokes with a glass-Teflon homogenizer in $10 \mathrm{ml}$ of homogenizing buffer $(118 \mathrm{mM}$ $\mathrm{NaCl}, 4.7 \mathrm{mM} \mathrm{KCl}, 1.2 \mathrm{mM} \mathrm{MgSO}_{4}, 2.5 \mathrm{mM} \mathrm{CaCl}_{2}, 1.53 \mathrm{mM} \mathrm{KH}_{2} \mathrm{PO}_{4}, 212.7 \mathrm{mM}$ glucose, $1 \mathrm{mM}$ DTT, pH7.4, and protease inhibitor) and filtered through a series of polypropylene filters (twice through $100 \mu \mathrm{m}$ and once through $10 \mu \mathrm{m}$ (BD Filcon). Filtrates were spun briefly $(1,000 \mathrm{~g}, 15 \mathrm{~min})$ and the pellets were reconstituted in $3 \mathrm{ml}$ of homogenizing buffer at a protein concentration of $1 \mathrm{mg} \mathrm{ml}^{-1}$. 
Dissected brain regions were homogenized in methanol $(1 \mathrm{ml})$ containing $\left[{ }^{2} \mathrm{H}_{8}\right]-2-\mathrm{AG}$ and N-heptadecanoylethanolamide (Cayman Chemicals, Ann Arbor, MI, USA) as internal standards. Protein concentration was determined in the homogenate to normalize samples using the bicinchinonic acid protein assay (Pierce, Rockford, IL, USA). Lipids were extracted with chloroform $(2 \mathrm{ml})$ and water $(1 \mathrm{ml})$, and further fractionated by open-bed silica gel column chromatography, as previously described ${ }^{52}$. Lipids were reconstituted in chloroform, loaded onto small glass columns packed with Silica Gel G (60- 2 230-400 Mesh ASTM; Whatman, Clifton, NJ, USA) and washed with $2 \mathrm{ml}$ of chloroform. 2 -AG were eluted with $1 \mathrm{ml}$ of chloroform/methanol $(9: 1, \mathrm{vol} / \mathrm{vol})$. Eluates were dried under $\mathrm{N}_{2}$ and reconstituted in chloroform/methanol $(1: 3,50 \mu \mathrm{l})$ for liquid chromatography/mass spectrometry (LC/MS) analyses.

An 1100-LC system coupled to a 1946A-MS detector (Agilent Technologies, Inc., Palo Alto, CA, USA) equipped with an electrospray ionization interface was used to measure anandamide and 2-AG levels in lipid extracts. Lipids were separated using a XDB Eclipse $\mathrm{C} 18$ column $(50 \times 4.6 \mathrm{~mm}$ i.d., $1.8 \mu \mathrm{m}$, Zorbax), eluted with a gradient of methanol in water (from 75 to $85 \%$ in $2.5 \mathrm{~min}$, to $90 \%$ in $7.5 \mathrm{~min}$, to $100 \%$ in $14 \mathrm{~min}$ and to $75 \%$ in $20 \mathrm{~min}$ ) at a flow rate of $1.0 \mathrm{ml} \mathrm{min}^{-1}$. Column temperature was kept at $40^{\circ} \mathrm{C}$. MS detection was in the positive ionization mode, capillary voltage was at $3 \mathrm{kV}$ and fragmentor voltage varied from $120 \mathrm{~V}$. $\mathrm{N}_{2}$ was used as drying gas at a flow rate of $131 \mathrm{~min}^{-1}$ and temperature of $350^{\circ} \mathrm{C}$. Nebulizer pressure was set at 60 PSI. Quantifications were conducted using an isotope-dilution method ${ }^{52}$ by monitoring $\mathrm{Na}^{+}$adducts of the molecular ions $\left([\mathrm{M}+\mathrm{Na}]^{+}\right)$in the selected ion-monitoring mode. Quantification limits for 2-AG was 0.4 pmol. For reverse transcriptase-PCR and quantitative PCR and immunoprecipitation, detailed procedures are provided in Supplementary Methods.

Results are expressed as the mean \pm s.e.m. Statistical significance was evaluated using the Student's $t$-test.

Animal behaviour. Adult male $f m r 1^{-1-} \mathrm{C} 57 \mathrm{BL} / 6 \mathrm{~J}$ mice were used for the animal behaviour studies. For open field and elevated plus maze, detailed procedures provided in Supplementary Methods ${ }^{53,54}$.

Anatomy. Experiments were performed according to the guidelines of the institutional ethical code and the Hungarian Act of Animal Care and Experimentation (1998; XXVIII. Section 243/1998). Adult male C57BL/6J mice (three wild-type and three $\mathrm{fmrl}^{-1-}$ mice (8 weeks old) were deeply anesthetized with a mixture of ketamine-xylazine ( $25 \mathrm{mg} \mathrm{ml}^{-1}$ ketamine, $5 \mathrm{mg} \mathrm{ml}^{-1}$ xylazine, $0.1 \% \mathrm{w} / \mathrm{w}$ pipolphen in $\mathrm{H}_{2} \mathrm{O} ; 1 \mathrm{ml}$ per $100 \mathrm{~g}$, intraperitoneal). Animals were then perfused transcardially with $0.9 \%$ saline for $2 \mathrm{~min}$, followed by $100 \mathrm{ml}$ of fixative containing $4 \%$ paraformaldehyde and $0.1 \%$ glutaraldehyde in $0.1 \mathrm{M}$ phosphate buffer (PB), $\mathrm{pH} 7.4$, for $20 \mathrm{~min}$. After perfusion, the brain was removed from the skull, cut into blocks, post-fixed for $2 \mathrm{~h}$ and washed in $\mathrm{PB}$. The blocks containing the ventral striatum were sliced into $50-\mu \mathrm{m}$-thick coronal sections of the brain with a Leica VTS-1000 vibratome (Vibratome, St Louis, MO, USA).

After slicing and extensive washing in $0.1 \mathrm{M} \mathrm{PB}$, the sections were incubated in $10 \%$ sucrose for $15 \mathrm{~min}$ and $30 \%$ sucrose overnight, followed by freeze thawing over liquid nitrogen four times. Subsequently, all washing steps and dilutions of the antibodies were performed in $0.05 \mathrm{M}$ Tris-buffered saline (TBS), pH 7.4. After extensive washing in TBS, the sections were blocked in 5\% normal goat serum for $45 \mathrm{~min}$ and then incubated in rabbit anti-DGL- $\alpha\left(1: 3,000\right.$, 'INT'; $\left.{ }^{13}\right)$ or rabbit anti$\mathrm{mGlu}_{5}(1: 1,000, \mathrm{AB} 5675$, Millipore, Billerica, MA, USA) for a minimum of $48 \mathrm{~h}$ at $4^{\circ} \mathrm{C}$. In the immunoperoxidase staining procedure, after primary antibody incubations, the sections were treated with biotinylated goat anti-rabbit IgG (1:400, Vector Laboratories) for $2 \mathrm{~h}$ and after three washes in TBS, with avidin biotinylatedhorseradish peroxidase complex (1:500; Elite ABC; Vector Laboratories) for $1.5 \mathrm{~h}$. After extensive washing, the immunoperoxidase reaction was developed using $3,3^{\prime}$-diaminobenzidine as the chromogen. In the immunogold staining procedure, after the primary antibody incubation, the sections were washed extensively in TBS before incubation in $0.8 \mathrm{~nm}$ gold-conjugated goat anti-rabbit secondary antibody (1:50; AURION, Wageningen, The Netherlands), overnight at $4^{\circ} \mathrm{C}$. Then sections were silver intensified using the silver enhancement system R-GENT SE-EM according to the kit protocol (AURION). After development of both types of immunolabelling, the sections were treated with osmium tetroxide $(0.5 \%$ for immunogold labelling, $1 \%$ for immunoperoxidase reaction) in $0.1 \mathrm{M} \mathrm{PB}$ for $20 \mathrm{~min}$ (at $4^{\circ} \mathrm{C}$ for immunogold labelling) and dehydrated in an ascending series of ethanol and acetonitrile, before being embedded in Durcupan (ACM, Fluka, Buchs, Switzerland). During dehydration, sections were treated with $1 \%$ uranyl acetate in $70 \%$ ethanol for $15 \mathrm{~min}$ (at $4^{\circ} \mathrm{C}$ for immunogold labelling). Immunoperoxidaselabelled sections were imaged with a Nikon Eclipse 80i microscope (Nikon Instruments Europe B.V., Amsterdam, The Netherlands) and light micrographs were captured with a DS-Fil digital camera (Nikon Instruments Europe B.V., Amsterdam, The Netherlands). For electron microscopy analysis, areas of interest in the ventral striatum core were removed from Durcupan-embedded sections, then re-embedded and re-sectioned. Ultrathin $(60 \mathrm{~nm})$ sections were collected on Formvar-coated single-slot grids and stained with lead citrate. Electron micrographs were taken at $\times 40,000$ magnifications with a Hitachi 7100 electron microscope (Tokyo, Japan).

Quantitative analysis of the distribution of $D G L-\alpha$ and $m G l u_{5}$ in dendritic spines: see Supplementary Methods.

\section{References}

1. Penagarikano, O., Mulle, J. G. \& Warren, S. T. The pathophysiology of fragile X syndrome. Аnnu. Rev. Genomics. Hum. Genet. 8, 109-129 (2007).

2. Verkerk, A. J. et al. Identification of a gene (FMR-1) containing a CGG repeat coincident with a breakpoint cluster region exhibiting length variation in fragile X syndrome. Cell 65, 905-914 (1991).

3. Ronesi, J. A. \& Huber, K. M. Metabotropic glutamate receptors and fragile $\times$ mental retardation protein: partners in translational regulation at the synapse. Sci. Signal. 1, pe6 (2008).

4. Kelleher, R. J. 3rd. \& Bear, M. F. The autistic neuron: troubled translation? Cell 135, 401-406 (2008).

5. Bear, M. F., Dolen, G., Osterweil, E. \& Nagarajan, N. Fragile X: translation in action. Neuropsychopharmacology 33, 84-87 (2008)

6. Dolen, G. et al. Correction of fragile X syndrome in mice. Neuron. 56, 955-962 (2007).

7. Huber, K. M., Gallagher, S. M., Warren, S. T. \& Bear, M. F. Altered synaptic plasticity in a mouse model of fragile X mental retardation. Proc. Natl Acad. Sci. USA 99, 7746-7750 (2002).

8. Robbe, D., Kopf, M., Remaury, A., Bockaert, J. \& Manzoni, O. J. Endogenous cannabinoids mediate long-term synaptic depression in the nucleus accumbens. Proc. Natl Acad. Sci. USA 99, 8384-8388 (2002).

9. Lafourcade, M. et al. Molecular components and functions of the endocannabinoid system in mouse prefrontal cortex. PLoS One. 2, e709 (2007).

10. Jung, K. M. et al. A key role for diacylglycerol lipase-alpha in metabotropic glutamate receptor-dependent endocannabinoid mobilization. Mol. Pharmacol. 72, 612-621 (2007).

11. Jung, K. M. et al. Stimulation of endocannabinoid formation in brain slice cultures through activation of group I metabotropic glutamate receptors. Mol. Pharmacol. 68, 1196-1202 (2005).

12. Tanimura, A. et al. The endocannabinoid 2-arachidonoylglycerol produced by diacylglycerol lipase alpha mediates retrograde suppression of synaptic transmission. Neuron 65, 320-327 (2010)

13. Katona, I. et al. Molecular composition of the endocannabinoid system at glutamatergic synapses. J. Neurosci. 26, 5628-5637 (2006)

14. Lujan, R., Nusser, Z., Roberts, J. D., Shigemoto, R. \& Somogyi, P. Perisynaptic location of metabotropic glutamate receptors mGluR1 and mGluR5 on dendrites and dendritic spines in the rat hippocampus. Eur. J. Neurosci. 8, 1488-1500 (1996).

15. Won, Y. J., Puhl, H. L. 3rd. \& Ikeda, S. R. Molecular reconstruction of mGluR5a-mediated endocannabinoid signaling cascade in single rat sympathetic neurons. J. Neurosci. 29, 13603-13612 (2009).

16. Dinh, T. P. et al. Brain monoglyceride lipase participating in endocannabinoid inactivation. Proc. Natl Acad. Sci. USA 99, 10819-10824 (2002).

17. Katona, I. \& Freund, T. F. Endocannabinoid signaling as a synaptic circuit breaker in neurological disease. Nat. Med. 14, 923-930 (2008).

18. Zhang, L. \& Alger, B. E. Enhanced endocannabinoid signaling elevates neuronal excitability in fragile X syndrome. J. Neurosci. 30, 5724-5729 (2010).

19. Maccarrone, M. et al. Abnormal mGlu 5 receptor/endocannabinoid coupling in mice lacking FMRP and BC1 RNA. Neuropsychopharmacology 35, 1500-1509 (2010).

20. Brown, V. et al. Microarray identification of FMRP-associated brain mRNAs and altered mRNA translational profiles in fragile X syndrome. Cell 107, 477-487 (2001).

21. Todd, P. K., Mack, K. J. \& Malter, J. S. The fragile X mental retardation protein is required for type-I metabotropic glutamate receptor-dependent translation of PSD-95. Proc. Natl Acad. Sci. USA 100, 14374-14378 (2003).

22. Westmark, C. J. \& Malter, J. S. FMRP mediates mGluR5-dependent translation of amyloid precursor protein. PLoS Biol. 5, e52 (2007).

23. Raiteri, L. \& Raiteri, M. Synaptosomes still viable after 25 years of superfusion. Neurochem. Res. 25, 1265-1274 (2000).

24. Yoshida, T. et al. Localization of diacylglycerol lipase-alpha around postsynaptic spine suggests close proximity between production site of an endocannabinoid, 2-arachidonoyl-glycerol, and presynaptic cannabinoid CB1 receptor. J. Neurosci. 26, 4740-4751 (2006).

25. Lujan, R., Roberts, J. D., Shigemoto, R., Ohishi, H. \& Somogyi, P. Differential plasma membrane distribution of metabotropic glutamate receptors mGluR1 alpha, mGluR2 and mGluR5, relative to neurotransmitter release sites. J. Chem. Neuroanat. 13, 219-241 (1997).

26. Bagni, C. \& Greenough, W. T. From mRNP trafficking to spine dysmorphogenesis the roots of fragile X syndrome. Nat. Rev. Neurosci. 6, 376-387 (2005).

27. Irwin, S. A., Galvez, R. \& Greenough, W. T. Dendritic spine structural anomalies in fragile-X mental retardation syndrome. Cereb. Cortex 10, 1038-1044 (2000).

28. Heifets, B. D. \& Castillo, P. E. Endocannabinoid signaling and long-term synaptic plasticity. Annu. Rev. Physiol. 71, 283-306 (2009).

29. Marrs, W. R. et al. The serine hydrolase ABHD6 controls the accumulation and efficacy of 2-AG at cannabinoid receptors. Nat. Neurosci. 13, 951-957 (2010) 
30. Mato, S., Lafourcade, M., Robbe, D., Bakiri, Y. \& Manzoni, O. J. Role of the cyclic-AMP/PKA cascade and of P/Q-type Ca. channels in endocannabinoidmediated long-term depression in the nucleus accumbens. Neuropharmacology 54, 87-94 (2008).

31. Robbe, D., Alonso, G., Chaumont, S., Bockaert, J. \& Manzoni, O. J. Role of p/q-Ca2+ channels in metabotropic glutamate receptor $2 / 3$-dependent presynaptic long-term depression at nucleus accumbens synapses. J. Neurosci. 22, 4346-4356 (2002).

32. Dinh, T. P., Freund, T. F. \& Piomelli, D. A role for monoglyceride lipase in 2-arachidonoylglycerol inactivation. Chem. Phys. Lipids 121, 149-158 (2002).

33. Long, J. Z. et al. Selective blockade of 2-arachidonoylglycerol hydrolysis produces cannabinoid behavioral effects. Nat. Chem. Biol. 5, 37-44 (2009).

34. Yuskaitis, C. J. et al. Lithium ameliorates altered glycogen synthase kinase-3 and behavior in a mouse model of fragile X syndrome. Biochem. Pharmacol. 79, 632-646 (2010).

35. Darnell, J. C. et al. FMRP stalls ribosomal translocation on mRNAs linked to synaptic function and autism. Cell 146, 247-261 (2011).

36. Piomelli, D. The molecular logic of endocannabinoid signalling. Nat. Rev. Neurosci. 4, 873-884 (2003).

37. Prescott, S. M. \& Majerus, P. W. The fatty acid composition of phosphatidylinositol from thrombin-stimulated human platelets. J. Biol. Chem. 256, 579-582 (1981).

38. Kao, D. I., Aldridge, G. M., Weiler, I. J. \& Greenough, W. T. Altered mRNA transport, docking, and protein translation in neurons lacking fragile $\mathrm{X}$ mental retardation protein. Proc. Natl Acad. Sci. USA 107, 15601-15606 (2010)

39. Roloff, A. M., Anderson, G. R., Martemyanov, K. A. \& Thayer, S. A. Homer la gates the induction mechanism for endocannabinoid-mediated synaptic plasticity. J. Neurosci. 30, 3072-3081 (2010).

40. Ronesi, J. A. \& Huber, K. M. Homer interactions are necessary for metabotropic glutamate receptor-induced long-term depression and translational activation. J. Neurosci. 28, 543-547 (2008).

41. Ronesi, J. A. et al. Disrupted Homer scaffolds mediate abnormal mGluR5 function in a mouse model of fragile X syndrome. Nat. Neurosci. 15, 431-440 (2012).

42. Suvrathan, A., Hoeffer, C. A., Wong, H., Klann, E. \& Chattarji, S Characterization and reversal of synaptic defects in the amygdala in a mouse model of fragile X syndrome. Proc. Natl Acad. Sci. USA 107, 11591-11596 (2011).

43. Chevaleyre, V. \& Castillo, P. E. Heterosynaptic LTD of hippocampal GABAergic synapses: a novel role of endocannabinoids in regulating excitability. Neuron 38, 461-472 (2003).

44. Krueger, D. D. \& Bear, M. F. Toward fulfilling the promise of molecular medicine in fragile X syndrome. Annu. Rev. Med. 62, 411-429 (2011).

45. Chanda, P. K. et al. Monoacylglycerol lipase activity is a critical modulator of the tone and integrity of the endocannabinoid system. Mol. Pharmacol. 78, 996-1003 (2010).

46. Schlosburg, J. E. et al. Chronic monoacylglycerol lipase blockade causes functional antagonism of the endocannabinoid system. Nat. Neurosci. 13, 1113-1119 (2010)

47. King, A. R. et al. Discovery of potent and reversible monoacylglycerol lipase inhibitors. Chem. Biol. 16, 1045-1052 (2009).

48. Pilpel, Y. et al. Synaptic ionotropic glutamate receptors and plasticity are developmentally altered in the CA1 field of Fmr1 knockout mice. J. Physiol. 587, 787-804 (2009)

49. Lafourcade, M. et al. Nutritional omega-3 deficiency abolishes endocannabinoidmediated neuronal functions. Nat. Neurosci. 14, 345-350 (2011).

50. Kasanetz, F. \& Manzoni, O. J. Maturation of excitatory synaptic transmission of the rat nucleus accumbens from juvenile to adult. J. Neurophysiol. 101, 2516-2527 (2009)

51. Villasana, L. E., Klann, E. \& Tejada-Simon, M. V. Rapid isolation of synaptoneurosomes and postsynaptic densities from adult mouse hippocampus. J. Neurosci. Methods 158, 30-36 (2006).

52. Astarita, G. \& Piomelli, D. Lipidomic analysis of endocannabinoid metabolism in biological samples. J. Chromatogr. B. Analyt. Technol. Biomed. Life. Sci. 877, 2755-2767 (2009)
53. Jarbe, T. U., Andrzejewski, M. E. \& DiPatrizio, N. V. Interactions between the CB1 receptor agonist Delta 9-THC and the CB1 receptor antagonist SR-141716 in rats: open-field revisited. Pharmacol. Biochem. Behav. 73, 911-919 (2002).

54. Lister, R. G. The use of a plus-maze to measure anxiety in the mouse. Psychopharmacology (Berl). 92, 180-185 (1987).

55. Evans, M. S., Collings, M. A. \& Brewer, G. J. Electrophysiology of embryonic adult and aged rat hippocampal neurons in serum-free culture. J. Neurosci. Methods 79, 37-46 (1998).

\section{Acknowledgements}

This work was supported by INSERM, ANR-Blanc France-Taiwan RescueMemo (O.J.M), FRAXA research foundation (M.S. and O.J.M.), a NARSAD 2010 Independent Investigator Grant given by the Brain and Behavior Research Foundation (O.J.M.), National Institute on Drug Abuse (DA-012447, D.P.), the Hungarian Scientific Research Fund-Norwegian Financial Mechanism Joint Program (NNF 78918), European Research Council Grant 243153 to I.K. and NIH grants (DA-011322 and DA-021696) to K.M.C.M.H. was a recipient of a European Molecular Biology Organization long-term fellowship. The contribution of the Agilent Technologies/University of California, Irvine Analytical Discovery Facility, Center for Drug Discovery is gratefully acknowledged. We acknowledge FRAXA research foundation (Dr D. Nelson, Baylor College of Medicine) for providing the Fmr1 KO2 mice. We thank Mr L. Barna, the Nikon Microscopy Center at IEM, Nikon Austria GmbH and Auro-Science Consulting Ltd for providing microscopy support and B. Dudok for his help in electron microscopy. We are grateful to Prof. Z. Nusser and Dr G. Nyíri for their help with statistical analysis. The technical assistance of Dr E. Horváth, G. Goda, B. Pintér, D. Thongkham and J. Lockney is also acknowledged. O.J.M. is grateful to Dr P. Chavis and Po-Wu Gean for helpful discussions and to R. Martinez for his help during the installation of the new laboratory.

\section{Author contributions}

K.-M.J. performed the biochemical and behavioural experiments, conducted data analyses, contributed to the experimental design and wrote the manuscript. M.S. performed the physiological experiments, conducted data analyses, contributed to the design of the experiments and wrote the manuscript. C.M.H. performed anatomical experiments, conducted data analyses, contributed to the experimental design and wrote the manuscript. O.L., D.N. and H.M. participated in the physiological experiments and conducted data analyses. N.V.D. participated in the behavioural experiments and conducted data analyses. A.F. and M.G. provided the $f m r 1^{-/-}$C57BL6/J mice, and K.M. provided the anti-DGL- $\alpha$ antibody. D.P. supervised and designed the biochemical and behavioural experiments, and wrote these sections of the manuscript; I.K. supervised and designed the anatomical experiments and wrote these sections of the manuscript; O.J.M. supervised and designed the physiological experiments and wrote these sections of the manuscript. D.P. and O.J.M. supervised the entire project and narrated the study.

\section{Additional information}

Supplementary Information accompanies this paper at http://www.nature.com/ naturecommunications

Competing financial interests: The authors declare no competing financial interests.

Reprints and permission information is available online at http://npg.nature.com/ reprintsandpermissions/

How to cite this article: Jung, K.-M. et al. Uncoupling of the endocannabinoid signalling complex in a mouse model of fragile X syndrome. Nat. Commun. 3:1080 doi: $10.1038 /$ ncomms2045 (2012)

License: This work is licensed under a Creative Commons Attribution-NonCommercialShare Alike 3.0 Unported License. To view a copy of this license, visit http:// creativecommons.org/licenses/by-nc-sa/3.0/ 